\title{
Rare ocular features in a case of Kabuki syndrome (Niikawa-Kuroki syndrome)
}

Yi-Hsing Chen ${ }^{1,2}$, Ming-Hui Sun ${ }^{1,2}$, Shao-Hsuan Hsia ${ }^{1,3}$, Chi-Chun Lai ${ }^{1,2}$ and Wei-Chi Wu $u^{1,2^{*}}$

\begin{abstract}
Background: Kabuki syndrome is a multi-system disorder with peculiar facial features, and ophthalmic abnormalities are frequently involved. This case report of a child with Kabuki syndrome describes two new previously unreported ophthalmic conditions.

Case presentation: A 3-year-old Taiwanese boy with Kabuki syndrome had a short stature, spinal dysraphism, intellectual disability and typical facial features. Ophthalmic findings which have been previously reported in the literature and in this patient, included ptosis, esotropia, coloboma of the iris, retina, choroid and optic disc, and microcornea. The newly identified ophthalmic features in this patient included colobomatous microphthalmos and a dysplastic and elevated disc without central cupping. The genetic analysis identified an MLL2 gene mutation.

Conclusion: The presentations of a dysplastic disc and colobomatous microphthalmia are rarely reported in patients with Kabuki syndrome, but these ophthalmic abnormalities may affect vision. Detailed ophthalmic evaluations in children with Kabuki syndrome are advised.
\end{abstract}

Keywords: Kabuki syndrome, Colobomatous microphthalmia, Optic disc dysplasia, MLL2 gene mutation

\section{Background}

Kabuki syndrome is a rare multi-system disorder that was first described in Japan [1,2]. To date, approximately 350 patients have been identified [3-5]. The principle diagnostic criteria for Kabuki syndrome include a short stature, skeletal anomalies, dermatoglyphic anomalies, intellectual disability, and characteristic facial features that resemble the make-up worn in Japanese Kabuki theatres [6]. However, other features, such as congenital heart disease, cleft palate, deafness and ophthalmic abnormalities, usually in the form of strabismus and ptosis, have been reported [3-5]. Most cases are sporadic, but familial cases of MLL2 gene mutations also exist [6-8]. We describe a case of Kabuki syndrome with an MLL2 gene mutation and rare features of colobomatous microphthalmos and a dysplastic optic disc. We also discuss the clinical overlap with CHARGE syndrome (coloboma, heart defects, atresia of the choanae, growth and development delay, genital hypoplasia, and ear anomalies).

\footnotetext{
* Correspondence: weichi666@gmail.com

'Department of Ophthalmology, Chang Gung Memorial Hospital, No. 5, Fu-Hsing Street, Kweishan, Taoyuan 333, Taiwan

${ }^{2}$ College of Medicine, Chang Gung University, Taoyuan, Taiwan

Full list of author information is available at the end of the article
}

\section{Case presentation}

A 3-year-old boy was brought to our emergency department due to a change in consciousness following a seizure attack. A physical examination revealed a short stature, low body weight, spinal dysraphism, and intellectual disability. He was admitted for acute and chronic subdural haemorrhage, pneumothorax and multiple rib fractures. The boy was claimed to have suffered head trauma at home, and his mother stated that he had longstanding poor vision. An ophthalmologist was consulted for the possibility of injury to the eyes.

The child had peculiar facial features with a depressed nasal tip, low-set deformed ears, and micrognathia. The external ophthalmic examination revealed arched eyebrows, epicanthus, ptosis, prominent eyelashes, long palpebral fissures, and eversion of the lateral portion of the lower eyelids in both eyes. In addition, microphthalmia in the right eye was noted (Figure 1A). The child had bilateral horizontal nystagmus and esotropia with limitation of abduction of 30 to $40 \%$ in the left eye. The visual acuity was no light perception in the right eye and counting finger(s) in the left eye. An examination under anaesthesia revealed a normal cornea in the left eye but a microcornea in the right eye. The anterior chamber and lens were 

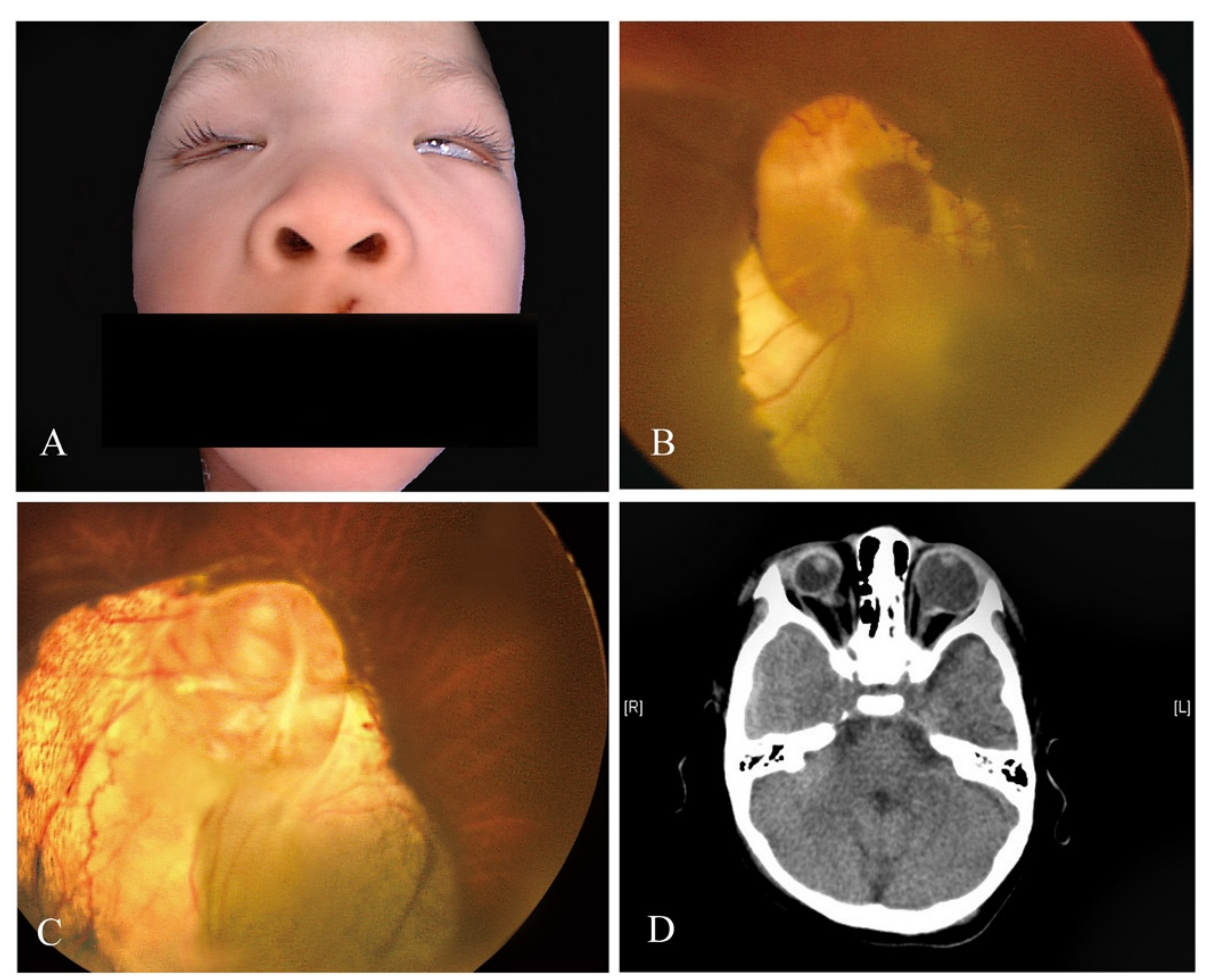

Figure 1 Photographs of the 3-year-old patient with Kabuki syndrome. (A) The external photograph shows arched eyebrows, epicanthus, ptosis, prominent eyelashes, long palpebral fissures, eversion of the lateral portion of the lower eyelids in both eyes, and depressed nasal tip. (B) The fundus photograph of the right eye shows coloboma of the retina, choroid and disc. (C) The fundus photograph of the left eye shows coloboma of the retina and choroid and an elevated optic disc without central cupping. (D) Computed tomography of the orbit reveals microphthalmia of the right eye and an isodense retrobulbar bulging cystic mass in both eyes. The defect is likely to be related to the colobomatous defect presented in the fundus photograph. No orbital fractures or intraorbital haemorrhages were found.

normal in both eyes. Iris and optic disc coloboma were discovered in the right eye (Figure 1B). In addition, retinal and choroidal coloboma in both eyes and an elevated optic disc without central cupping in the left eye were found (Figure 1C). There was no evidence of retinal or vitreous haemorrhage. Computed tomography of the orbit showed isodense retrobulbar bulging cystic masses in both eyes, which were likely related to the colobomatous defect. In addition, colobomatous microphthalmia in the right eye was discovered. No orbital fracture or intraorbital haemorrhage was found (Figure 1D). A diagnosis of shaken baby syndrome was excluded based on these findings.

A detailed review of the literature illustrates that various ophthalmic abnormalities have been associated with Kabuki syndrome. In the present case, there was neither a history of consanguinity in the parents nor peculiar faces in other family members. Further genetic study revealed that the patient had a normal 46XY chromosome pattern but an MLL2 gene mutation.

\section{Discussion}

The prevalence of Kabuki syndrome is estimated to be 1 in 32,000 births in Japan [5]. The most common ophthalmic abnormalities in Kabuki syndrome are strabismus and ptosis, with reported incidence rates of $20.5 \%$ and $14.4 \%$, respectively [3]. Coloboma is a less common feature that has been reported in $3.2 \%$ of the published cases [3]. Other rare abnormalities, such as nystagmus, microphthalmos, microcornea, corneal opacities, blue sclera, cataracts, nasolacrimal duct obstruction, jaw-winking type of ptosis, caruncle lipoma, corneal pannus, retinal telangiectasia, and retinal pigmentation, have been reported in Kabuki syndrome [3,5,9]. However, the presentation of colobomatous microphthalmia and a dysplastic disc is rare [3]. Moreover, a dysplastic disc and lack of central cupping has not been reported previously to the best of our knowledge.

Kabuki syndrome shows a phenotypic overlap with CHARGE syndrome [10-13]. Shared presentations include cleft palate, development delay, genital hypoplasia, congenital heart, and ear, eye and renal abnormalities [11-13]. Shared ophthalmic phenotypes include coloboma and staphyloma $[3,14]$. CHARGE syndrome was initially considered a likely diagnosis in our patient because of the features of coloboma, growth and development delay, and ear abnormality. However, he fulfilled only two major and 
two minor criteria; therefore, he could not be clinically diagnosed with CHARGE syndrome. In addition, he had typical Kabuki facial presentations. The genetic survey can assist in establishing the diagnosis from a molecular level. The most common genotypic presentation in Kabuki syndrome is the MLL2 gene mutation [6-8], which contrasts to the CHD7 gene mutation found in CHARGE syndrome [11]. Our patient had an MLL2 gene mutation, which further supported the diagnosis of Kabuki syndrome.

\section{Conclusions}

Ophthalmic abnormalities are frequently associated with Kabuki syndrome. A dysplastic elevated disc without central cupping and colobomatous microphthalmia are rare ophthalmic abnormalities in patients with Kabuki syndrome. Careful ophthalmic evaluations should be performed for each patient.

\section{Consent}

Written informed consent was obtained from the parents of the patients for publication of this case report and any accompanying images. A copy of the written consent is available for review by the Editor-in-Chief of this journal.

\section{Competing interests}

The authors declare that they have no competing interests.

\section{Authors' contribution}

YHC conducted the literature search and drafted the manuscript. MHS and WCW conceived the idea for the manuscript, conducted the literature search and critically revised the manuscript. SHH and CCL critically revised the manuscript. All authors read and approved the final manuscript.

\section{Author details}

'Department of Ophthalmology, Chang Gung Memorial Hospital, No. 5, Fu-Hsing Street, Kweishan, Taoyuan 333, Taiwan. ${ }^{2}$ College of Medicine, Chang Gung University, Taoyuan, Taiwan. ${ }^{3}$ Department of Pediatrics, Chang Gung Memorial Hospital, Taoyuan, Taiwan.

Received: 20 May 2013 Accepted: 18 November 2014

Published: 24 November 2014

\section{References}

1. Niikawa N, Matsuura N, Fukushima Y, Ohsawa T, Kajii T: Kabuki make-up syndrome: a syndrome of mental retardation, unusual facies, large and protruding ears, and postnatal growth deficiency. J Pediatr 1981, 99:565-569.

2. Kuroki Y, Suzuki Y, Chyo H, Hata A, Matsui I: A new malformation syndrome of long palpebral fissures, large ears, depressed nasal tip, and skeletal anomalies associated with postnatal dwarfism and mental retardation. J Pediatr 1981, 99:570-573.

3. Ming JE, Russell KL, Bason L, McDonald-McGinn DM, Zackai EH: Coloboma and other ophthalmologic anomalies in Kabuki syndrome: distinction from charge association. Am J Med Genet A 2003, 123A:249-252.

4. Adam MP, Hudgins L: Kabuki syndrome: a review. Clin Genet 2005, 67:209-219.

5. Matsumoto N, Niikawa N: Kabuki make-up syndrome: a review. Am J Med Genet C Semin Med Genet 2003, 117C:57-65.

6. Hannibal MC, Buckingham KJ, Ng SB, Ming JE, Beck AE, McMillin MJ, Gildersleeve HI, Bigham AW, Tabor HK, Mefford HC, Cook J, Yoshiura K, Matsumoto T, Matsumoto N, Miyake N, Tonoki H, Naritomi K, Kaname T, Nagai T, Ohashi H, Kurosawa K, Hou JW, Ohta T, Liang D, Sudo A, Morris CA, Banka S, Black GC, Clayton-Smith J, Nickerson DA, et al: Spectrum of MLL2
(ALR) mutations in 110 cases of Kabuki syndrome. Am J Med Genet A 2011, 155A:1511-1516.

7. Ng SB, Bigham AW, Buckingham KJ, Hannibal MC, McMillin MJ, Gildersleeve HI, Beck AE, Tabor HK, Cooper GM, Mefford HC, Lee C, Turner EH, Smith JD, Rieder MJ, Yoshiura K, Matsumoto N, Ohta T, Niikawa N, Nickerson DA, Bamshad MJ, Shendure J: Exome sequencing identifies MLL2 mutations as a cause of Kabuki syndrome. Nat Genet 2010, 42:790-793.

8. Paulussen AD, Stegmann AP, Blok MJ, Tserpelis D, Posma-Velter C, Detisch Y, Smeets EE, Wagemans A, Schrander JJ, van den Boogaard MJ, Van der Smagt J, Van HA, Stolte-Dijkstra I, Kerstjens-Frederikse WS, Mancini GM, Wessels MW, Hennekam RC, Vreeburg M, Geraedts J, de Ravel T, Fryns JP, Smeets HJ, Devriendt K, Schrander-Stumpel CT: MLL2 mutation spectrum in 45 patients with Kabuki syndrome. Hum Mutat 2011, 32:E2018-E2025.

9. Evans SL, Kumar N, Rashid MH, Hughes DS: New ocular findings in a case of Kabuki syndrome. Eye (Lond) 2004, 18:322-324.

10. Pagon RA, Graham JM Jr, Zonana J, Yong SL, Yong SL: Coloboma, congenitalheart disease, and choanal atresia with multiple anomalies: CHARGEassociation. J Pediatr 1981, 99:223-227.

11. Schulz Y, Freese L, Mänz J, Zoll B, Völter C, Brockmann K, Bögershausen N, Becker J, Wollnik B, Pauli S: CHARGE and Kabuki syndromes: a phenotypic and molecular link. Hum Mol Genet 2014, 23(16):4396-4405.

12. Verhagen JM, Oostdijk W, Terwisscha Van Scheltinga CE, Schalij-delfos NE, van Bever $Y$ : An unusual presentation of Kabuki syndrome: clinical overlap with CHARGE syndrome. Eur J Med Genet 2014, 57(9):510-512.

13. Geneviève D, Amiel J, Viot G, Le Merrer M, Sanlaville D, Urtizberea A, Gérard M, Munnich A, Cormier-Daire V, Lyonnet S: Atypical findings in Kabuki syndrome: report of 8 patients in a series of 20 and review of the literature. Am J Med Genet A 2004, 129(1):64-68.

14. Tanaka R, Takenouchi T, Uchida K, Sato T, Fukushima H, Yoshihashi H, Takahashi T, Tsubota K, Kosaki K: Congenital corneal staphyloma as a complication of Kabuki syndrome. Am J Med Genet A 2012, 158A:2000-2002.

\section{doi:10.1186/1471-2415-14-143}

Cite this article as: Chen et al:: Rare ocular features in a case of Kabuki syndrome (Niikawa-Kuroki syndrome). BMC Ophthalmology 2014 14:143.

\section{Submit your next manuscript to BioMed Central and take full advantage of:}

- Convenient online submission

- Thorough peer review

- No space constraints or color figure charges

- Immediate publication on acceptance

- Inclusion in PubMed, CAS, Scopus and Google Scholar

- Research which is freely available for redistribution 